\title{
Uranium (VI) sorption from sulphuric solutions by AM-p-2 anionite
}

\author{
Vadym Korovin ${ }^{1, *}$, Oleksandr Valiaiev ${ }^{1}$, Oleksandr Zontov ${ }^{2}$, Larysa Zontova ${ }^{2}$, Volodymyr \\ Pilchyk ${ }^{3}$, and Borys Pysmennyi ${ }^{3}$ \\ ${ }^{1}$ Institute of Geotechnical Mechanics named by N. Poljakov of National Academy of Sciences of \\ Ukraine, 49005, Dnipro, Simferopolska Str., 2a, Ukraine \\ ${ }^{2}$ Smoly State Enterprise, 51917, Kamianske, Anoshkina Ave., 179, Ukraine \\ ${ }^{3}$ VostGOK State Enterprise, 52210, Zhovti Vody, Horkoho Str., 2, Ukraine
}

\begin{abstract}
Research results were presented for equilibrium and kinetics of uranium sorption by AM-p-2 strong-base anionite from model sulphuric solution. Kinetic experimental data agreed with the pseudo second-order model while equilibrium ones - with the modified Langmuir-Freundlich equation. Testing of the anionite including sorption-desorption process operations used at uranium-mining industrial facilities showed that the resin had high sorption-desorption characteristics.
\end{abstract}

\section{Introduction}

Sorption materials are widely used for uranium selective recovery due to their complete insolubility in aqueous phase, low rate of physical destruction, sorption and kinetic properties and osmotic stability [1]. For this purpose, organic and inorganic cation- and anion exchangers are applied $[2,3]$ as well as materials that combine properties of selective liquid extractant and a sorbent - impregnated resins and solid extractants (known by TVEX trademark) [4].

Previously, we demonstrated [5] the conceptual possibility of uranium recovery from tails accumulated at Zakhidne (Western) tailing dump using sorption leaching from pulp by AMP anionite. We have tested anionites Cybber USX 500T, Ambersep 920U, Purolite A 500 [6-8] for uranium recovery from sulphate and carbonate media. Uranium selective extraction by TVEX containing diisooctylmethyl phosphonate [9] and calixareneimpregnated resin was studied in [10]. We also tested phosphate cation exchanger based on modified plant material (apricot stone) for uranium recovery from radioactivelycontaminated water accumulated in the basement of the industrial building at the former Production Union Pridneprovsk Chemical Plant [11]

Ambersep 920U anionite manufactured by Dow Chemical is among the most common anion exchangers used currently for uranium recovery during its in-situ leaching [3, 12]. AM-p-2 anion exchanger synthesized at Smoly State Enterprise is its analogue [13, 14].

This paper presents the result of the uranium sorption study by AM-p-2 anionite from model sulphate solutions and its testing during uranium recovery from sulphate heap leaching solution of VostGOK State Enterprise.

\footnotetext{
*Corresponding author: sorbent2005@ukr.net
} 


\section{Methods}

\subsection{Materials and reagents}

AM-p-2 anionite is a strong-base anion exchange resin based on macroporous styrene-divinyl benzene copolymer and containing 2-hydroxyethyl-dimethylammonium functional groups $\left(-\mathrm{N}^{+}\left(\mathrm{CH}_{3}\right)_{2} \mathrm{CH}_{2} \mathrm{CH}_{2} \mathrm{OH}\right)$. It features the following parameters: ionic form $-\mathrm{SO}_{4}$ (at least $50 \%$ ); total exchange capacity - at least $1.0 \mathrm{mmole} / \mathrm{cm}^{3}$; moisture retention $-55 \%$ to $56 \%$, particle size range $-0.8 \mathrm{~mm}$ to $1.25 \mathrm{~mm}$, effective size fraction ratio $-99 \%$, uniformity factor - max 1.4, mechanical strength $-99 \%$, bulk density- $660 \mathrm{~g} / \mathrm{dm}^{3}$ to $680 \mathrm{~g} / \mathrm{dm}^{3}$.

All reagents used were at least of reagent grade.

\subsection{Experimental technique}

Uranium equilibrium distribution between AM-p-2 and model uranyl sulphate solution containing $0.52 \mathrm{~g} / \mathrm{dm}^{3}$ of uranium, $25 \mathrm{~g} / \mathrm{dm}^{3}$ of sodium sulphate and $p H=1.45$ was studied in static mode by the different portion technique at a temperature of $20 \pm 2{ }^{\circ} \mathrm{C}$ and contact time 24 hours. Sorption kinetics was studied using the solution limited volume method at phase ratio solid:liquid $=1: 200$ within 24 hours. The study was carried out at a temperature of $20 \pm 2{ }^{\circ} \mathrm{C}$ from the same model solution using a temperature-controlled stirrer.

AM-p-2 anionite was tested in dynamic mode including sorption-desorption process operations used today at uranium-mining industrial facilities.

Uranium sorption was carried out from the heap leaching process solution of VostGOK State Enterprise $\quad\left([U]=0.158 \mathrm{~g} / \mathrm{dm}^{3}, \quad\left[\mathrm{Fe}^{3+}\right]=0.54 \mathrm{~g} / \mathrm{dm}^{3}, \quad\left[\mathrm{Fe}^{2+}\right]=0.27 \mathrm{~g} / \mathrm{dm}^{3}, \quad\left[\mathrm{NO}_{3}{ }^{-}\right]=0.18 \mathrm{~g} / \mathrm{dm}^{3}\right.$, $p H=1.64$ ) in a column of $24 \mathrm{~mm}$ in diameter with the solution feed rate 7 bed volumes per hour. The volume of the charged initial anionite in sulphate-carbonate form was $100 \mathrm{~cm}^{3}$. Uranium concentration in the solution at the column output was measured every 2 hours. The process was stopped after uranium concentration equalization in the initial solution and at the column output.

Anionite was additionally saturated with artificial solution: $[U]=28.8 \mathrm{~g} / \mathrm{dm}^{3}$, $\left[\mathrm{NO}_{3}{ }^{-}\right]=9.9 \mathrm{~g} / \mathrm{dm}^{3},\left[\mathrm{SO}_{4}{ }^{2-}\right]=51.2 \mathrm{~g} / \mathrm{dm}^{3}$, acidity $20.44 \mathrm{~g} / \mathrm{dm}^{3}$ with feed rate 1 bed volume per hour. This solution had been prepared from ammonium uranyl tricarbonate, nitric and sulphuric acids. Uranium content was measured in the solution at the column output every hour. Additional resin saturation was stopped after equalization of uranium concentrations in the initial solutions and at the column output.

Uranium was stripped from the saturated anionite with the solution containing $\left[\mathrm{NO}_{3}{ }^{-}\right]=102.32 \mathrm{~g} / \mathrm{dm}^{3} ;\left[\mathrm{HNO}_{3}\right]=25 \mathrm{~g} / \mathrm{dm}^{3},\left[\mathrm{H}_{2} \mathrm{SO}_{4}\right]=1 \mathrm{~g} / \mathrm{dm}^{3}, C_{\text {excess. }}=20 \mathrm{~g} / \mathrm{dm}^{3}$, which had been prepared from ammonium nitrate, sulphuric and nitric acids. The feed rate was 1 bed volume per hour. Uranium content was measured in the stripping solution at the column output every hour. Uranium desorption was stopped after achieving its concentration in the solution at the column output less than $0.1 \mathrm{~g} / \mathrm{dm}^{3}$.

Resin denitration was carried out with feed ratel bed volume per hour with the solution containing $50.86 \mathrm{~g} / \mathrm{dm}^{3}$ of sulphuric acid. Denitration was stopped when nitrate-ion concentration at the column output was less than $1 \mathrm{~g} / \mathrm{dm}^{3}$. The nitrate-ion concentration was measured at the column output every hour.

\subsection{Analytical techniques}

Uranium concentration in model and process solutions was measured by titrimetric method [12]. Resin capacity was calculated by the difference of uranium concentration in liquid phase before and after sorption in equivalent to the absolutely dry weight of the resin. 
Anionite capacity during its testing with process solutions was determined by complete uranium stripping from the resin. For this purpose, $5 \mathrm{~cm}^{3}$ of averaged resin sample preliminarily washed with distilled water was contacted several times for a short period with $190 \mathrm{~g} / \mathrm{dm}^{3}$ sulphuric acid at volumetric phase ratio liquid:solid=20:1 per one contact at a temperature of $60{ }^{\circ} \mathrm{C}$. Duration of a single contact was 3 minutes; the number of contacts was 15 . Measurement of residual resin capacity by uranium was carried out similarly; the number of contacts was decreased to 10 .

After each operation, specific volume was measured. For this purpose, the fixed anionite sample undergone uranium complete desorption, washing from sulphuric acid and drying at $80^{\circ} \mathrm{C}$ until constant weight.

The nitrate-ion concentration was measured by back titration of the ammonium ferrous sulphate excess with the potassium bichromate solution.

\section{Results and discussion}

\subsection{Uranium sorption from model sulphuric solution}

Figure 1 illustrates the plot of AM-p-2 anionite equilibrium capacity $q$ versus uranium equilibrium concentration $[U]_{e q}$ during its sorption from the model solution containing $25 \mathrm{~g} / \mathrm{dm}^{3}$ of sodium sulphate and $p H=1.45$.

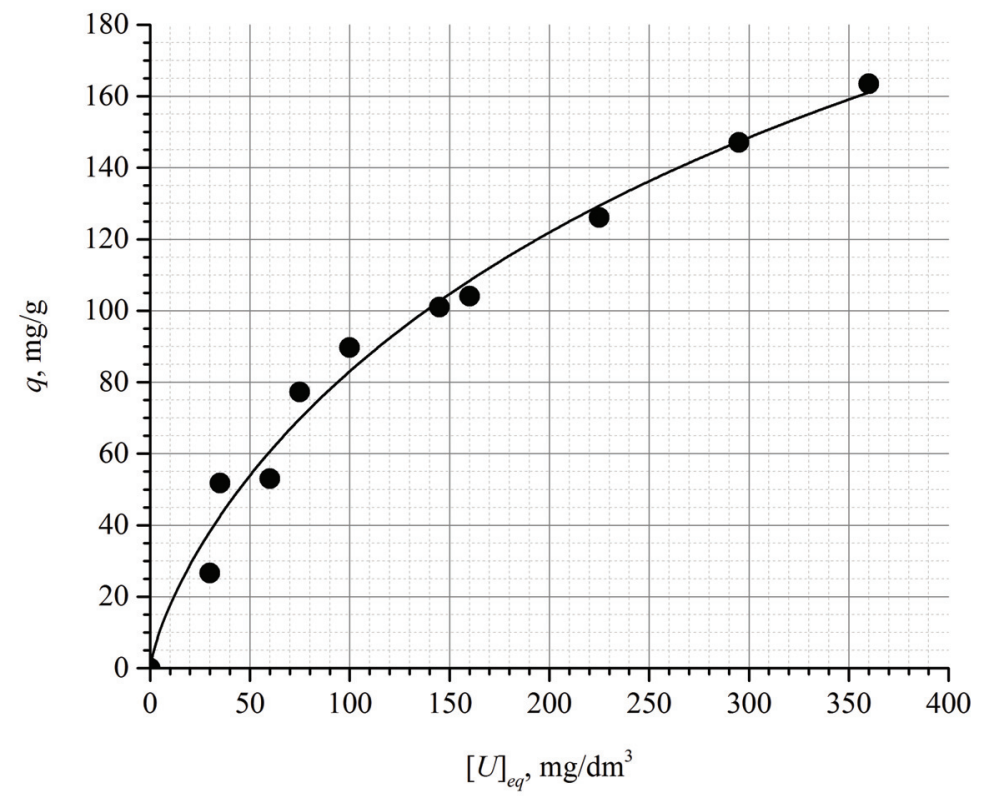

Fig. 1. Uranium sorption isotherm by AM-p-2 anionite: $(\bullet)$ experimental data, (-) Langmuir-Freundlich fit.

It is seen from the data presented that the anionite has high capacitive characteristics.

Experimental results were processed by the most widely used Langmuir and Freundlich fitting models in a linearized form. They were also processed by the modified Langmuir-Freundlich model using nonlinear regression analysis. Data processing results are given in Table 1.

Within the studied range of uranium concentrations $20 \mathrm{mg} / \mathrm{dm}^{3}$ to $400 \mathrm{mg} / \mathrm{dm}^{3}$, experimental data were fit with high correlation factor $\left(R^{2}=0.9980\right)$ by the modified Langmuir-Freundlich equation with the following parameters: maximum capacity $q_{m}=373.8 \mathrm{mg} / \mathrm{g}$, constant $K_{L F}=8.570 \cdot 10^{-3} \mathrm{dm}^{3} / \mathrm{mg}$. 
Table 1. Parameters of the sorption isotherm equations.

\begin{tabular}{|c|c|c|}
\hline Equation & Parameters & Value \\
\hline \multirow{3}{*}{$\begin{array}{c}\text { Freundlich } \\
q=K_{F} \cdot[U]_{e q}^{1 / n_{F}}\end{array}$} & Constant $K_{F},(\mathrm{mg} / \mathrm{g}) /\left(\mathrm{mg} / \mathrm{dm}^{3}\right)^{1 / n}$ & 4.499 \\
\hline & Empiric coefficient $n_{F}$ & 1.611 \\
\hline & Correlation factor $R^{2}$ & 0.9191 \\
\hline \multirow{3}{*}{$q=\frac{\begin{array}{c}\text { Langmuir } \\
q_{m} \cdot K_{L} \cdot[U]_{e q}\end{array}}{1+K_{L} \cdot[U]_{e q}}$} & Maximum capacity $q_{m}, \mathrm{mg} / \mathrm{g}$ & 242.7 \\
\hline & Constant $K_{L}, \mathrm{dm}^{3} / \mathrm{mg}$ & $5.239 \cdot 10^{-3}$ \\
\hline & Correlation factor $R^{2}$ & 0.9218 \\
\hline \multirow{3}{*}{$\begin{array}{c}\text { Langmuir - } \\
\text { Freundlich } \\
q=\frac{q_{m} \cdot K_{L F} \cdot[U]_{e q}^{n_{L F}}}{}\end{array}$} & Maximum capacity $q_{m}, \mathrm{mg} / \mathrm{g}$ & 373.8 \\
\hline & Constant $K_{L F}, \mathrm{dm}^{3} / \mathrm{mg}$ & $8.570 \cdot 10^{-3}$ \\
\hline & Heterogenicity $n_{L F}$ & 0.7612 \\
\hline $1+K_{L F} \cdot\left[U\left[_{e q}^{n_{L F}}\right.\right.$ & Correlation factor $R^{2}$ & 0.9980 \\
\hline
\end{tabular}

Figure 2 shows the integral kinetic curve of uranium sorption by AM-p-2 anionite from model uranyl sulphate solution containing $0.52 \mathrm{~g} / \mathrm{dm}^{3}$ of uranium, $25 \mathrm{~g} / \mathrm{dm}^{3}$ of sodium sulphate and $p H=1.45$.

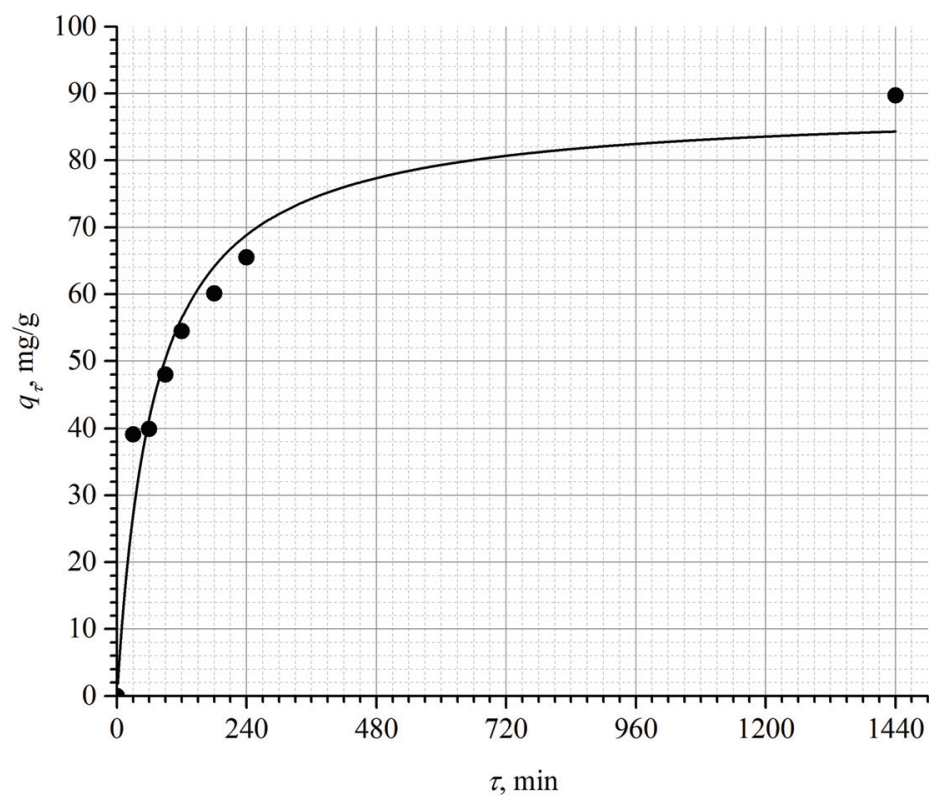

Fig. 2. Integral kinetic curve of uranium sorption by AM-p-2 anionite: $(\bullet)$ experimental data, (- pseudosecond order fit.

As it is seen from the data obtained, the anionite features high kinetic characteristics; thus, $80 \%$ of uranium recovery took place during 4 hours.

Assessment of the kinetic curve plotted in coordinate systems $X-\tau^{1 / 2}$, and $\ln (1-X)-\tau$ (where: $\tau$ is time, $X=q_{\tau} / q_{\text {exp }}, q_{\tau}$, is anionite capacity at time point $\tau ; q_{\text {exp }}$ is experimental equilibrium capacity) indicated that both liquid-film and intra-particle diffusion affected sorption rate.

Sorption kinetics was quantitatively described using pseudo-first order, pseudo-second order kinetic models and Elovich equation in linearized form; their parameters are given in Table 2. 
Table 2. Kinetic data processing results.

\begin{tabular}{|c|c|c|}
\hline \multirow{2}{*}{ Model equation } & Parameters & Value \\
\hline \multirow{2}{*}{$\begin{array}{c}\text { Pseudo-first-order } \\
q_{\tau}=q_{e}\left(1-\exp \left(-k_{1} \cdot \tau\right)\right)\end{array}$} & Calculated equilibrium capacity $q_{e}, \mathrm{mg} / \mathrm{g}$ & 58.15 \\
\cline { 2 - 3 } & Rate constant $k_{1}, \mathrm{~min}^{-1}$ & $3.731 \cdot 10^{-3}$ \\
\cline { 2 - 3 } Pseudo-second-order & Correlation factor $R^{2}$ & 0.9797 \\
\cline { 2 - 3 }$q_{\tau}=\frac{\tau \cdot k_{2} \cdot q_{e}^{3}}{q_{e}+\tau \cdot k_{2} \cdot q_{e}^{2}}$ & Rate constant $k_{2}, \mathrm{~g} / \mathrm{mg} \mathrm{min}$ & 94.61 \\
\cline { 2 - 3 } & Correlation factor $R^{2}$ & $1.257 \cdot 10^{-4}$ \\
\hline \multirow{2}{*}{ Elovich } & Initial sorption rate $h[1], \mathrm{mg} / \mathrm{g} \mathrm{min}$ & 1.128 \\
\cline { 2 - 3 }$q_{\tau}=\frac{1}{\beta} \ln (\alpha \beta)+\frac{1}{\beta} \ln (\tau)$ & Initial sorption rate $\alpha, \mathrm{mg} / \mathrm{g} \mathrm{min}$ & 5.525 \\
\cline { 2 - 3 } & Desorption constant $\beta, \mathrm{g} / \mathrm{mg}$ & 0.9743 \\
\hline \multicolumn{2}{|c|}{ Experimental equilibrium capacity $q_{\text {exp }}, \mathrm{mg} / \mathrm{g}$} & 89.70 \\
\hline
\end{tabular}

The pseudo-second-order model fit most precisely $\left(R^{2}=0.9983\right)$ experimental data (Fig. 2) while calculated $q_{e}$ and experimental $q_{\text {exp }}$ capacity had similar values $94.61 \mathrm{mg} / \mathrm{g}$ and $89.70 \mathrm{mg} / \mathrm{g}$, correspondingly. Rate constant $k_{2}$ for the pseudo-second order model was $1.257 \cdot 10^{-4} \mathrm{~g} /(\mathrm{mg} \cdot \mathrm{min})$. The similar results were obtained in [1] when studying uranium sorption by Ambersep 920U.

\subsection{Testing of AM-p-2 anionite in dynamic mode}

Figure 3 illustrates the uranium breakthrough curve from the heap leaching solution at VostGOK State Enterprise containing uranium initial concentration $[U]_{0}=0.158 \mathrm{~g} / \mathrm{dm}^{3}$ in coordinates $F=[U] /[U]_{0}$, where $[U]$ was the current uranium concentration in a sample versus the number of fed bed volumes $V k$.

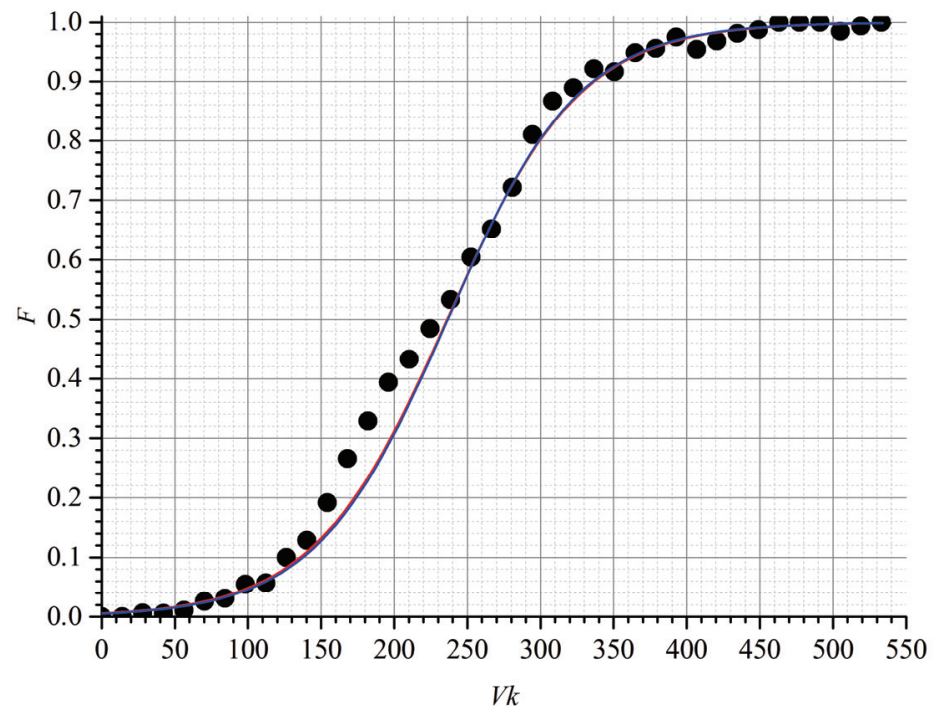

Fig. 3. Uranium breakthrough curve for AM-p-2 anionite: (•) experimental data, (-) model fit.

Maximum volumetric sorption capacity in dynamic mode was $30.19 \mathrm{mg} / \mathrm{cm}^{3}$ during uranium sorption from the heap leaching solution. Weight capacity by uranium for the absolutely dry resin was $91.48 \mathrm{mg} / \mathrm{g}$ with a specific resin volume $3.03 \mathrm{~cm}^{3} / \mathrm{g}$. 
The uranium breakthrough was processed by Yoon-Nelson, Thomas and BDST models applied to fit the relationship between uranium concentration in eluate and the sorption time at a given feed rate of the test solution through the column. The data processing results are shown in Table 3 and Figure 3.

Table 3. Parameters of adsorption models for bed processes as compared with experimental data.

\begin{tabular}{|c|c|c|}
\hline Model & Parameters & Value \\
\hline \multirow{3}{*}{ Experimental data } & Maximum sorption capacity $q_{\text {exp }}, \mathrm{mg} / \mathrm{g}$ & 91.48 \\
\cline { 2 - 3 } & Sorption capacity of the bed $N_{\text {exp }}, \mathrm{g} / \mathrm{dm}^{3}$ & 30.19 \\
\cline { 2 - 3 } & Time required for the $50 \%$ breakthrough $\tau_{\text {exp }}, \mathrm{min}$ & 1605 \\
\hline \multirow{2}{*}{ Thomas } & Thomas kinetic coefficient $K_{T h}, \mathrm{~cm}^{3} /(\mathrm{mg} \cdot \mathrm{min})$ & 0.0156 \\
\cline { 2 - 3 } & Sorption capacity $q_{0}, \mathrm{mg} / \mathrm{g}$ & 103.3 \\
\hline \multirow{2}{*}{ BDST } & Sorption rate constant $K_{B D S T}, \mathrm{~cm}^{3} /(\mathrm{mg} \cdot \mathrm{min})$ & 0.0163 \\
\cline { 2 - 3 } & Sorption capacity of the bed $N_{0}, \mathrm{~g} / \mathrm{dm}^{3}$ & 34.36 \\
\hline \multirow{2}{*}{ Yoon-Nelson } & Yoon-Nelson rate of constant $K_{Y N}, 1 / \mathrm{min}$ & 0.0025 \\
\cline { 2 - 3 } & Time required for the $50 \%$ breakthrough $\tau_{Y N}, \mathrm{~min}$ & 1849 \\
\hline \multicolumn{2}{|c}{} & 0.9590 \\
\hline
\end{tabular}

It is seen from the data obtained that the anionite sorption capacity by Thomas model is $103.3 \mathrm{mg} / \mathrm{g}(91.48 \mathrm{mg} / \mathrm{g}$ in the experiment) while the time required for the $50 \%$ uranium breakthrough by the Yoon-Nelson model is 1849 minutes (1605 minutes in the experiment). Kinetic coefficients by Thomas and Yoon-Nelson models were similar. Models correctly $\left(R^{2}=0.9590\right)$ described experimental data.

The volumetric capacity of the resin was $51.12 \mathrm{mg} / \mathrm{cm}^{3}$ during additional saturation using the artificial solution containing $[U]=28.8 \mathrm{~g} / \mathrm{dm}^{3}$, in equivalent to absolutely dry resin $148.25 \mathrm{mg} / \mathrm{g}$ at resin specific volume $2.90 \mathrm{~cm}^{3} / \mathrm{g}$. Thus, anionite had the high additional saturation of $69.3 \%$ (more than $40 \%$ ) that provided obtaining of concentrated desorbate.

Figure 4 shows the results of uranium stripping with artificial sulphate-nitrate solution in coordinates uranium concentration in desorbate $[U] /$ uranium stripping degree $(s)$ in percent versus the number of fed bed volumes $V k$.

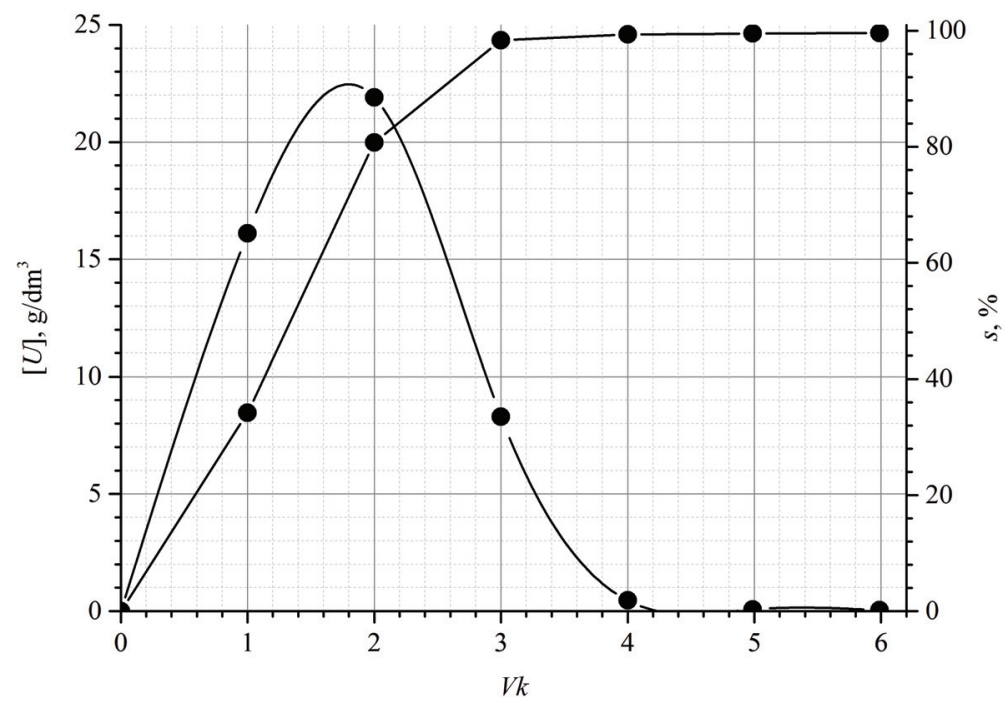

Fig. 4. Uranium content in desorbate (1) and its stripping rate (2) versus the number of desorbate bed volumes. 
It is seen from the data given that almost all uranium (by $99.34 \%$ ) was stripped after feeding 4 bed volumes of the solution with feed rate 1 bed volume per hour. Residual volumetric capacity by uranium was $0.22 \mathrm{mg} / \mathrm{cm}^{3}$, in equivalent to absolutely dry resin $0.65 \mathrm{mg} / \mathrm{g}$ at resin specific volume $2.94 \mathrm{~cm}^{3} / \mathrm{g}$.

Resin denitration was carried out using the artificial solution containing $50.86 \mathrm{~g} / \mathrm{dm}^{3}$ of sulphuric acid. Residual volumetric capacity by nitrate-ion was $1.93 \mathrm{mg} / \mathrm{cm}^{3}$, in equivalent to absolutely dry resin $-5.98 \mathrm{mg} / \mathrm{g}$ at resin specific volume $3.1 \mathrm{~cm}^{3} / \mathrm{g}$.

\section{Conclusions}

As a result of the study, it was established that the uranium sorption equilibrium by AM-p-2 anion exchanger from the model sulphate solution was described by the modified Langmuir Freundlich equation within the studied range of uranium concentrations. Sorption kinetics was most accurately described with the pseudo-second-order model.

Testing of the anionite including sorption-desorption process operations used at uraniummining industrial facilities showed that the resin had high sorption-desorption characteristics and met the requirements for the ion exchangers imposed in the uranium-processing industry.

Optimal structure of the AM-p-2 polymer matrix provided high mechanical and osmotic strength thus allowing its use in hydrometallurgical processes including sorption from pulps.

\section{References}

1. Mohamed F. Cheira, Bahig M. Atia, Mohamed N. Kouraim, Journal of Radiation Research and Applied Sciences. 10, 307-319 (2017)

2. Kenzhaliyev, B.K., Dosymbayeva, Z.D, Berkinbayeva, A.N, Suleimenov, E.N, Sharipov, R.Kh, Zheksembiyeva, B.T., Int. Jour. of Eng. and App. Sci. 4, 14 (2017)

3. Adelbaev, I.E., Shokobaev, N.M. (2014). Study of sorption-desorption characteristics of modern anionites during uranium recovery from in-situ leaching solutions. Iadernyi potentsial Respubliki Kazakhstan. Sbornik dokladov. Assotsiatsiia "Iadernoe obshchestvo Kazakhstana". Astana. 69-73

4. V. Korovin, Yu. Shestak, Yu. Pogorelov, and J.-L. Cortina, Solvent Extraction and Liquid Membranes: Fundamentals and Applications in New Materials. Ed.: M. Aguilar, J.-L. Cortina. - CRC Press, Taylor \& Francis Group, 261-301 (2008)

5. Soroka, Yu.N., Mochanov, A.I., Podrezov, A.A., Kaulko, E.A., Korovin, V.Yu., Pogorelov, Yu.N., Merkulov, V.A., Valyaev, A.M. (2011). Assessing the Potential for Uranium Additional Recovery from Radioactive Waste Contained at the Zapadnoye Tailing Dump, Materialy 8-oj mezhdunarodnoj konferencii "Sotrudnichestvo dlja reshenija problem othodov" [Proc. of the $8^{\text {th }}$ International conference "Cooperation for Solving Problems of Wastes"]

6. Petrakova, O., Korovin, V., Olifirenko, A, IEX 2012: The International Ion Exchange Conference, Cambridge, UK, 19-21 September 2012, 67-68 (2012)

7. Korovin, V., Petrakova, O., Olifirenko, A., Kozlov, V. (2012). Application of macroporous ionites Cybber in the processes of complex uranium-containing raw material processing, IV All-Russian Conference on chemical engineering, All-Russian Youth Conference on chemical engineering, All-Russian school on chemical engineering for young scientists and specialists (accessed 18 February 2019)

8. Korovin, V.Yu., Tikhonov, A.N., Barbanov, A.V. (2013). Uranium sorption with CYBBER USX 500T anionite from industrial solutions, Materialy 2-oj Rossiyskoy konferentsii s mezhdunarodnym uchastiem "Novye podhody $v$ khinicheskoy technologii mineralnogo syria. Primenenie sortsii I ekstraktsii" [Proc. of the $2^{\text {nd }}$ 
Russian conference with international participation "New approaches to chemical tehnology of mineral raw materials. Application of sorption and extraction"], SaintPetersburg, 3-6 June 2013, 54-56

9. Korovin, V.Yu., Shestak, Yu.G., Valyaev, A.M. and Korovin, Yu.F. (2015). Uranium extraction by TVEX-DIOMP, Tezisy dokladov mezhdunarodnogo nauchnogo simpoziuma nedelya ekologa-2015 [Abstracts of the International Scientific Symposium Week Environmentalist-2015] Environmentalist Week - 2015, Dneprodzerzhinsk, 13-16 April 2015, 250-253

10. Krasnoperova, A.P., Yukhno, G.D., Ternova, D.S., Miroshnichenko, S.I., Korovin, V.Yu., Korovin, Yu.F., Kalchenko, V.I. (2013). Uranium (IV) extraction by porous styrene-divinyl benzene co-polymer impregnated with calixarene tetraphosphineoxide, Dopovidi Natsionalnoyi Akademiyi nauk Ukrainy [Reports of the National Academy of Sciences of Ukraine], 11, 124-129

11. Valyaev, A.M., Korovin, V.Yu, Lavrova, T.V. (2018). Purification of radioactivelycontaminated water with phosphate cationite based on modified plant raw material. XXV shchorichba naukova konferentsiia Instytutu yadernykh doslidzhen NAN Ukrainy, Kyiv, 16 - 20 kvitnia 2018 roku: tezy dopovidei. - Kyiv: In-t Yadernykh Doslidzh., 207-208

12. A.N. Zagorodnyaya, Z.S. Abisheva, A.S. Sharipova, S.E. Sadykanova, Ye.G. Bochevskaya, O.V. Atanova, Hydrometallurgy. 131-132, 127-132 (2013)

13. Korovin, V.Yu, Pogorelov, Yu.N., Zontov, A.V, Zontova, L.V. (2018). Rhenium and uranium sorption by AM-p-2 and AMR anionites from sulphuric acids. Intensifikatsiia gidrometallurgicheskikh protsessov pererabotki prirodnogo i tekhnogennogo syria Tekhnologii i oborudovanie Mezhdunarodnaia nauchno-prakticheskaia konferentsiia Materialy nauchno-prakticheskoi konferentsii Sankt-Peterburg 28 maia 1 iiunia 2018 g. Trudy, 159-162

14. Korovin, V.Yu, Valyaev, A.M., Zontov, A.V., Zontova, L.V., Pilchik, V.V., Pismennyi, B.V. (2018). Sorption-desorption characteristics of AM-p-2 anionite during uranium recovery from heal leaching solutions. XX Ukrainska konferentsiia $z$ neorganichnoi khimii, Dnipro, 17-20 veresnia 2018 roku: tezy dopovidey, 201 